\title{
PENGARUH HARGA EMAS DUNIA, HARGA MINYAK MENTAH DUNIA DAN INDEKS PRODUKSI INDUSTRI TERHADAP INDEKS SAHAM DI JAKARTA ISLAMIC INDEX (JII) DALAM JANGKA \\ PANJANG DAN JANGKA PENDEK \\ (PERIODE JANUARI 2005-DESEMBER 2015) 1)
}

\author{
Dwi Purnamasari \\ Mahasiswa Program Studi Ekonomi Islam-Fakultas Ekonomi dan Bisnis-Universitas Airlangga \\ Email: purnamasari2201@gmail.com \\ Raditya Sukmana \\ Departemen Ekonomi Syariah-Fakultas Ekonomi dan Bisnis-Universitas Airlangga \\ Email: momyadit@gmail.com
}

\begin{abstract}
:
This research aims to know the influence of long-term and short-term world gold price, the price of crude oil to the world, and the index of industrial production against the stock index at the Jakarta Islamic Index (JII) during the period January to December 2015-2015. The object of this research is the stock index at the Jakarta Islamic Index (JII). Types of data used are secondary data. This research method using technical analysis with quantitative method of Error Correction Mechanism (ECM). The results showed that significant influence world gold prices in the long term and the short term against a stock index of JII. While the price of crude oil the world significant negative effect on the long run, and a significant positive effect on the short term. The index of industrial production turned out to be only a significant effect in the long term, but not in the short term.
\end{abstract}

Keywords: the stock index, the Jakarta Islamic Index, the price of gold, the world price of crude oil, indices of industrial production.

\section{PENDAHULUAN}

\section{Latar Belakang}

Dalam pandangan Islam, investasi memiliki makna yang sama dengan pandangan secara umum atau konvensional, yakni kegiatan mengembangkan vang melalui pemanfaatan berbagai sumber daya dengan motivasi untuk mendapatkan keuntungan yang sejalan dengan prinsip syariah (Rivai dkk, 2010:422). Salah satu prinsip-prinsip syariah yakni adalah tanpa mengandung adanya unsur maysir (perjudian), gharar (penipuan), dan riba' (penambahan). Ketiga unsur tersebut juga merupakan unsur-unsur yang dilarang adanya dalam semua kegiatan perekonomian dalam Islam. Konsep investasi dalam Islam selain sebagai pengetahuan juga bernuansa spiritual karena menggunakan norma syariah, sekaligus merupakan hakikat dari sebuah ilmu dan amal, oleh karena itu investasi sangat dianjurkan bagi setiap muslim (Huda, 2008:18). Hal ini dijelaskan dalam Al-Qur'an surat al-Hasyr ayat 18 sebagai berikut:

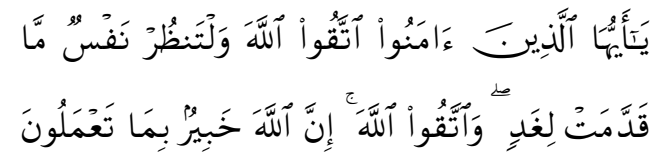

Yā ayyuha'I-lażīna āmanū ittaqū'lLāha waltanzur nafsu'm-Mā qaddamat lighadi'w-Waittaqū'lLāha inna'l-Lāha khabīru'mBimāta'malūna

"Hai orang-orang yang beriman, bertakwalah kepada Allah dan hendaklah setiap diri memperhatikan apa yang telah

1) Jurnal ini merupakan bagian dari skripsi yang ditulis oleh Dwi Purnamasari, NIM: 041114002 yang diuji pada tanggal 11 Agustus 2016. 
Purnamasari, et al/Jurnal Ekonomi Syariah Teori dan Terapan Vol. 4 No. 7 Juli 2017: 515-530; PENGARUH HARGA EMAS DUNIA, HARGA MINYAK MENTAH DUNIA DAN INDEKS PRODUKSI INDUSTRI TERHADAP INDEKS SAHAM DI JAKARTA ISLAMIC INDEX (JII) DALAM JANGKA PANJANG DAN JANGKA PENDEK (PERIODE JANUARI 2005-DESEMBER 2015)

diperbuatnya untuk hari esok (akhirat); dan bertakwalah kepada Allah, sesungguhnya Allah Maha Mengetahui apa yang kamu kerjakan." (Al Qur'an Kementrian Agama Rl : 2014)

Maksud dari ayat di atas adalah bahwa setiap manusia diperintahkan untuk memperhatikan apa yang telah kita lakukan dan kita perbuat, untuk menyiapkan diri di hari esok. Sehingga manusia hendaknya berinvestasi sebagai bekal di dunia dan di akhirat. Investasi yang dapat dilakukan adalah dengan berusaha dan bekerja secara halal untuk mencari rejeki di dunia, serta beribadah dan mengamalkan amalan sholeh untuk bekal di akhirat (Utomo, 2014:6). Islam memandang penting kegiatan berinvestasi sehingga seorang muslim dihadapkan pada dua pilihan yaitu untuk berinvestasi atau dikenakan zakat pada vangnya yang menganggur (Lestari, 2011:174). Maka, investasi sebenarnya merupakan bentuk kegiatan dari ekonomi Islam yang wajib dilakukan, sebab setiap harta ada zakatnya, jika harta tersebut didiamkan, maka lambat laun akan termakan oleh zakat. Hikmah dari zakat itu sendiri adalah mendorong untuk setiap muslim menginvestasikan hartanya. Investasi juga merupakan solusi untuk menghindari penimbunan harta.

Keberadaan pasar modal di Indonesia merupakan salah satu faktor yang menggerakkan perekonomian Indonesia, terbukti telah banyak industri dan perusahaan yang menggunakan institusi pasar modal ini sebagai media untuk menyerap investasi dan media untuk memperkuat posisi keuangannya (Alma, 2009:41). Undang-Undang Republik Indonesia Nomor 8 Tahun 1995 tentang Pasar Modal menjelaskan bahwa pasar modal adalah kegiatan yang bersangkutan dengan penawaran umum dan perdagangan efek, perusahaan publik yang berkaitan dengan efek yang diterbitkannya serta lembaga profesi yang berkaitan dengan efek. Pasar modal merupakan pasar untuk perdagangan saham perusahaan yang dipegang umum dan instrumen finansial yang berhubungan (termasuk opsi saham, perdagangan dan prakiraan indeks saham) (www.wikipedia.com). Menurut Samsul (2006:179) indeks saham adalah harga saham yang dinyatakan dalam angka indeks. Indeks saham juga dapat digunakan dengan tujuan analisis dan menghindari dampak negatif dari penggunaan harga saham dalam rupiah.

Seiring perkembangan jaman, Pasar Modal Syariah di Indonesia mulai diluncurkan dengan diterbitkannya Reksa Dana Syariah oleh PT. Danareksa Investment Management pada 3 Juli 1997. Selanjutnya, Bursa Efek Indonesia bekerjasama dengan PT. Danareksa Investment Management meluncurkan Jakarta Islamic Index pada tanggal 3 Juli 2000 yang bertujuan untuk memandu investor yang ingin menginvestasikan dananya secara syariah. Kemudian, pada 12 Mei 2011, Bursa Efek Indonesia (BEI) mengeluarkan Indeks Saham Syariah Indonesia (ISSI) yang merupakan 
Purnamasari, et al/Jurnal Ekonomi Syariah Teori dan Terapan Vol. 4 No. 7 Juli 2017: 515-530; PENGARUH HARGA EMAS DUNIA, HARGA MINYAK MENTAH DUNIA DAN INDEKS PRODUKSI INDUSTRI TERHADAP INDEKS SAHAM DI JAKARTA ISLAMIC INDEX (JII) DALAM JANGKA PANJANG DAN JANGKA PENDEK (PERIODE JANUARI 2005-DESEMBER 2015)

kumpulan dari saham yang berada di Daftar Efek Syariah (DES) dan tercatat di BEl. Sehingga Indonesia kemudian mempunyai dua indeks saham syariah yakni Jakarta Islamic Index (JII) dan Indeks Saham Syariah Indonesia (ISSI).

Adapun Jakarta Islamic Index (JII) lebih selektif dibandingkan Indeks Saham Syariah Indonesia (ISSI). Setiap periodenya, saham yang masuk Jll berjumlah 30 (tiga puluh) saham yang dinilai tidak melanggar prinsip syariah. Sutedi (2011: 53) mengungkapkan tujuan pembentukan JII adalah untuk meningkatkan kepercayaan investor untuk melakukan investasi pada saham berbasis syariah. JII juga menjadi pemandu bagi investor yang ingin menanamkan dananya secara syariah tanpa takut tercampur dengan dana ribawi. Selain itu JII menjadi tolak ukur kinerja dalam memilih portofolio saham yang halal. Penentuan kriteria dalam pemilihan saham dalam JII melibatkan Dewan Pengawas Syariah.

Ada beberapa syarat dan proses penyaringan terlebih dahulu yang harus dilalui untuk dapat masuk ke JII.

Menurut Alwi (2003) dalam Wicaksono (2014:7), ada beberapa faktor yang mempengaruhi pergerakan harga saham atau indeks harga saham, yaitu:

1. Faktor Internal (Lingkungan mikro) a. Pengumuman tentang pemasaran, produksi, penjualan seperti pengiklanan, rincian kontrak, perubahan harga, penarikan produk baru, laporan produksi, laporan keamanan produk, dan laporan penjualan.

b. Pengumuman pendanaan (financing announcements), seperti pengumuman yang berhubungan dengan ekuitas dan hutang.

c. Pengumuman badan direksi manajemen (managementboard of director announcements) seperti perubahan dan pergantian direktur, manajemen, dan struktur organisasi.

d. Pengumuman pengambilalihan diversifikasi, seperti laporan merger, investasi ekuitas, laporan take over oleh pengakuisisian dan diakuisisi, laporan divestasi dan lainnya.

e. Pengumuman investasi (investment announcements), seperti melakukan ekspansi pabrik, pengembangan riset dan, penutupan usaha lainnya..

f. Pengumuman ketenagakerjaan (labour announcements), seperti negoisasi baru, kontrak baru, pemogokan dan lainnya.

g. Pengumuman laporan keuangan perusahaan, seperti peramalan laba sebelum akhir tahun fiskal dan setelah akhir tahun fiskal, earning per share (EPS) dan dividen per share (DPS), price earning ratio, net profit margin, return on assets (ROA), dan lain-lain.

2. Faktor eksternal (Lingkungan makro)

a. Pengumuman dari pemerintah seperti perubahan suku bunga tabungan dan deposito, kurs valuta asing, inflasi, serta berbagai regulasi dan deregulasi ekonomi yang dikeluarkan oleh pemerintah.

b. Pengumuman hukum (legal announcements), seperti tuntutan karyawan terhadap perusahaan atau terhadap manajernya dan tuntutan perusahaan terhadap manajernya.

c. Pengumuman industri sekuritas (securities announcements), seperti laporan pertemuan tahunan, insider trading, volume atau harga saham perdagangan, 
Purnamasari, et al/Jurnal Ekonomi Syariah Teori dan Terapan Vol. 4 No. 7 Juli 2017: 515-530; PENGARUH HARGA EMAS DUNIA, HARGA MINYAK MENTAH DUNIA DAN INDEKS PRODUKSI INDUSTRI TERHADAP INDEKS SAHAM DI JAKARTA ISLAMIC INDEX (JII) DALAM JANGKA PANJANG DAN JANGKA PENDEK (PERIODE JANUARI 2005-DESEMBER 2015)

pembatasan/penundaaan trading.

d. Gejolak politik dalam negeri dan fluktuasi nilai tukar juga merupakan faktor yang berpengaruh signifikan pada terjadinya pergerakan harga saham di bursa efek suatu negara.

Baik di dalam pasar modal konvensional maupun pasar modal syariah, informasi memiliki peran penting karena dapat mempengaruhi tingkah laku investor dalam menentukan strategi bisnisnya. Oleh karena itu, informasi yang lengkap, relevan, akurat dan tepat waktu sangat dibutuhkan investor. Ibaratnya, pasar modal tanpa informasi adalah judi..

Menelaah pada faktor yang mempengaruhi harga saham maupun indeks harga saham, naik turunnya grafik pasar modal bisa dikatakan dapat dipengaruhi oleh variabel makroekonomi, termasuk harga emas, harga minyak mentah, bahkan indeks produksi industri (Gokmenoglu dan Fazlollahi, 2015).

Hubungan antara pasar keuangan dan komoditas merupakan salah satu masalah yang paling menantang bagi investor. Ketidakpastian mengenai gejolak perekonomian di masa mendatang menjadi kekhawatiran tersendiri bagi investor pemula bahkan pemilik saham. Penelitian ini penting untuk dilakukan karena dapat digunakan sebagai keputusan dalam berinvestasi. Adanya kepentingan calon investor, pemilik saham serta manajer investasi terhadap pergerakan Jakarta Islamic Index (JII) memunculkan suatu kebutuhan akan adanya penelitian mengenai pengaruh jangka panjang dan jangka pendek harga emas dunia, harga minyak mentah dunia, dan indeks produksi industri terhadap indeks saham di Jakarta Islamic Index (JII). Sehingga terkait akan hal tersebut penelitian ini dilakukan.

\section{LANDASAN TEORI}

Investasi merupakan kegiatan mengembangkan harta kekayaan dengan cara-cara tertentu yang melibatkan aktifitas dan risiko (Wahid, 2010:80). Maksudnya adalah pemilik modal (investor) menanamkan sahamnya dalam aktifitas yang melibatkan dirinya dalam mekanisme investasi tersebut sehingga dengan sendirinya ia akan menerima kemungkinan keuntungan dan kerugian sebagai risiko dari aktifitas investasinya. Dalam perspektif Islam, investasi adalah kegiatan yang sangat dianjurkan karena dapat mendorong pertumbuhan ekonomi yang ditandai dengan meningkatnya transaksi jual-beli, simpan-pinjam, sewa-menyewa, gadai, dan kegiatan ekonomi lainnya (Suryomurti, 2011:3). Menurut Riyandono (2009:34) investasi syariah adalah pengorbanan sumber daya pada masa sekarang untuk mendapatkan hasil yang lebih besar dimasa yang akan dating, baik langsung maupun tidak langsung seraya tetap berpijak pada prinsip syariah yang menyeluruh (kaffah).

Menurut Dr. Qutb Sano (2000:58-80) tujuan investasi pada dasarnya adalah sebagai berikut:

1. Menjaga kekekalan penyuburan harta dan pertambahannya 
Purnamasari, et al/Jurnal Ekonomi Syariah Teori dan Terapan Vol. 4 No. 7 Juli 2017: 515-530; PENGARUH HARGA EMAS DUNIA, HARGA MINYAK MENTAH DUNIA DAN INDEKS PRODUKSI INDUSTRI TERHADAP INDEKS SAHAM DI JAKARTA ISLAMIC INDEX (JII) DALAM JANGKA PANJANG DAN JANGKA PENDEK (PERIODE JANUARI 2005-DESEMBER 2015)

2. Menjaga kekekalan pertukaran harta

3. Memastikan kesenangan yang sempurna bagi individu dan masyarakat.

Sedangkan tujuan investasi dalam Islam bukan semata-mata hanya untuk menambah harta kekayaan yang dimiliki, tetapi untuk mendekat kepada Allah SWT (Jaka, 2009:218). Investasi yang aman secara duniawi belum tentu aman dari sisi akhirat. Artinya, investasi yang sangat menguntungkan sekalipun dan tidak melanggar hukum positif yang berlaku belum tentu aman jika dilihat dari sisi syariah Islam (Karim, 2005:140).

Pasar modal merupakan pasar untuk berbagai instrument keuangan jangka panjang yang bisa diperjual belikan, baik surat utang (obligasi), saham, reksadana, maupun instrumen lainnya (Rivai dkk, 2010:531). Untuk menghargai konsep Islam dalam pasar modal, layak untuk dilihat pada instrumen keuangan yang tersedia di pasar modal konvensional.

Fatwa DSN-MUI No. 40/DSN-MUI/2003 tentang pasar modal dan pedoman umum penerapan prinsip syariah di biadang pasar modal sebagai berikut:

1. Bahwa perkembangan ekeonomi suatu Negara tidak lepas dari perkembangan pasar modal;

2. Bahwa pasar modal berdasarkan prinsip syariah telah dikembangnkan di berbagai Negara

3. Bahwa umat Islam Indonesia memerlukan Pasar Modal yang aktivitasnya sejalan dengan prinsip syariah;

4. Bahwa oleh karena itu, untuk memenuhi kebutuhan tersebut, Dewan Syariah Nasional MUI memandang perlu menetapkan fatwa tentang Pasar Modal dan Pedoman Umum Penerapan Prinisip Syariah di Bidang Pasar Modal.

Hidayat (2011:23) menyatakan bahwa:

"sebagai bagian dari karunia Allah, Islam menganjurkan umatnya untuk tidak mendiamkan atau menumpuk hartanya, akan tetapi menggunakannya secara produktif melalui berbagai muamalah dan transaksi yang dibenarkan secara syariah".

Untuk itu investasi adalah salah satu cara yang digunakan untuk mengembangkan harta kekayaan yang dimiliki secara produktif. Banyaknya pilihan produk investasi yang ditawarkan kemudian menjadikan investasi memiliki banyak wadah yang bisa digunakan, namun tidak serta merta sesuai dengan syariah. Banyak produk investasi yang memiliki peluang return tinggi, namun keuntungan yang diperoleh dalam berinvestasi secara syariah tidak hanya keuntungan secara duniawi, namun juga secara ukhrawi.

Produk syariah di pasar modal antara lain berupa surat berharga atau efek. Berdasarkan Undang-undang Nomor 8 Tahun 1995 tentang Pasar Modal (UUPM, efek adalah surat berharga yaitu surat pengakuan utang, surat berharga komersial, saham, obligasi, tanda bukti utang, unit penyertaan kontrak investasi kolektif, kontrak berjangka atas efek, dan setiap derivatif dari efek (www.ojk.go.id). Efek syariah menurut peraturan Badan Pengawas Pasar Modal dan Lembaga 
Purnamasari, et al/Jurnal Ekonomi Syariah Teori dan Terapan Vol. 4 No. 7 Juli 2017: 515-530; PENGARUH HARGA EMAS DUNIA, HARGA MINYAK MENTAH DUNIA DAN INDEKS PRODUKSI INDUSTRI TERHADAP INDEKS SAHAM DI JAKARTA ISLAMIC INDEX (JII) DALAM JANGKA PANJANG DAN JANGKA PENDEK (PERIODE JANUARI 2005-DESEMBER 2015)

Kevangan (BAPEPAM-LK) Nomor IX.A.13 tentang Penerbitan Efek Syariah adalah sebagaimana yang dimaksud dalam UUPM dan pelaksanaan akad, cara, dan kegiatan usaha yang menjadi landasan pelaksanaannya tidak bertentangan dengan prinsip-prinsip syariah di pasar modal.

Hartono (2012:100) menyatakan bahwa suatu indeks diperlukan sebagai sebuah indikator untuk mengamati pergerakan harga dari sekuritas-sekuritas. Hartono kembali menyebutkan beberapa indeks yang dimiliki Bursa Efek Indonesia (BEI) sampai sekarang yaitu Indeks Harga Saham Gabungan (IHSG), Index Liquid 45 (ILQ45), Jakarta Islamic Index (JII), Indeks Papan Utama dan Indeks Papan Pengembangan, dan Indeks Kompas 100.

Jakarta Islamic Index (JII) pertama diluncurkan pada tanggal 3 Juli 2000 oleh Bursa Efek Indonesia (BEI) dan kerjasama dengan PT. Danareksa Invesment Management. Dimaksudkan untuk menjadi tolak ukur dalam mengatur kinerja suatu investasi pada saham dengan basis syariah, JII juga diharapkan dapat meningkatkan kepercayaan investor untuk mengembangkan investasi dalam ekuiti secara syariah (www.idx.co.id). Pembentukan instrumen syariah ini untuk mendukung pembentukan Pasar Modal Syariah yang kemudian diluncurkan di Jakarta pada tanggal 14 Maret 2003. Mekanisme Pasar Modal Syariah meniru pola serupa di Malaysia yang digabungkan dengan bursa konvensional seperti Bursa Efek
Jakarta dan Bursa Efek Surabaya. Setiap periodenya, saham yang masuk JII berjumlah 30 (tiga puluh) saham yang memenuhi kriteria syariah. JII menggunakan hari dasar tanggal 1 Januari 1995 dengan nilai dasar 100 (www.bi.go.id)

Dewan Syari'ah Nasional Majelis Ulama Indonesia (DSN-MUI) mengeluarkan fatwa No: 40/DSN-MUI/X/2003 tentang Pasar Modal dan Pedoman Umum Penerapan Prinsip Syariah di Bidang Pasar Modal. Berdasarkan fatwa tersebut pada pasal 3 angka 2 mengenai kriteria emiten atau perusahaan publik yang menerbitkan efek syariah, jenis kegiatan usaha tidak boleh yang bertentangan dengan prinsip-prinsip syariah.

Alwi (2003) dalam Wicaksono (2014:7), menyebutkan bahwa ada beberapa faktor yang mempengaruhi pergerakan harga saham atau indeks harga saham

Samsul (2006:190) menambahkan bahwa kondisi makro perekonomian suatu negara merupakan salah satu faktor yang dapat mempengaruhi kinerja perusahaan-perusahaan yang ada di negara tersebut. Hartono (2012:518) menyatakan bahwa pada ada umumnya, ketika informasi yang datang ke pasar modal bersifat positif, maka harga saham dan indeks akan bergerak naik. Sebaliknya, jika informasi yang datang bersifat negatif, maka akan memicu terjadinya tekanan jual sehingga harga saham dan indeks akan mengalami penurunan. Indikator-indikator 
Purnamasari, et al/Jurnal Ekonomi Syariah Teori dan Terapan Vol. 4 No. 7 Juli 2017: 515-530; PENGARUH HARGA EMAS DUNIA, HARGA MINYAK MENTAH DUNIA DAN INDEKS PRODUKSI INDUSTRI TERHADAP INDEKS SAHAM DI JAKARTA ISLAMIC INDEX (JII) DALAM JANGKA PANJANG DAN JANGKA PENDEK (PERIODE JANUARI 2005-DESEMBER 2015)

makroekonomi yang mempengaruhi pergerakan indeks saham pada penelitian ini antara lain: harga emas dunia, harga minyak mentah dunia, dan indeks produksi industri.

Sejak tahun 1968, harga emas yang dijadikan patokan seluruh dunia adalah harga emas berdasarkan standar pasar emas London. Sistem ini dinamakan London Gold Fixing Ltd. Setiap awal periode perdagangan, presiden London Gold Fixing Ltd akan mengumumkan suatu harga tertentu. Kemudian lima anggota tersebut akan mengabarkan harga kepada dealer. Dealer inilah yang berhubungan langsung dengan para pembeli sebenarnya dari emas yang diperdagangkan. Posisi akhir harga yang ditawarkan oleh setiap dealer kepada anggota Gold London Fixing merupakan posisi bersih dari hasil akumulasi permintaan dan penawaran klien mereka. Dari sinilah harga emas akan terbentuk. Apabila permintaan lebih banyak dari penawaran, otomatis harga akan naik, begitu pula sebaliknya. Penentuan harga yang pasti menunggu hingga tercapainya titik keseimbangan.

Harga minyak Brent merupakan campuran dari 15 jenis minyak mentah yang dihasilkan oleh 15 ladang minyak yang berbeda di Laut Utara. Kualitas minyak jenis ini memang tidak sebaik minyak mentah jenis WTI, meski begitu tetap bagus untuk disuling menjadi bahan bakar. Harga minyak Brent lebih rendah sekitar satu hingga dua dolar dari harga minyak WTI, tetapi lebih tinggi empat dolar dari harga minyak Organization of Petroleum Exporting Countries (OPEC). OPEC adalah organisasi antar pemerintah yang berdiri tahun 1960 dan bertujuan menegosiasikan masalah-masalah mengenai produksi, harga dan hak konsesi minyak bumi dengan perusahaanperusahaan minyak. Negara anggotanya adalah negara eksportir minyak yang saat ini terdiri dari Arab Saudi, Iran, Irak, Kuwait, Venezuela, Nigeria, Aljazair, Qatar, Libya, UAE dan Indonesia. Sebelumnya Equador, Gabon juga menjadi anggota tetapi kemudian keluar pada tahun 1992 dan 1994. Kemudian pada Mei 2008, Indonesia menyusul keluar dari organisasi ini (ditpolkom.bappenas.go.id). Sehingga semenjak keluarnya Indonesia dari OPEC, Indonesia tidak lagi menjadi negara pengekspor minyak, namun menjadi net importir.

Indeks produksi industri merupakan salah satu indikator yang mencerminkan status ekonomi nasional (Fatkhurrozaq, 2012:17). Indeks ini menunjukkan volume produksi industri dan mengukur output industri. Indeks ini berdampak pada semua indikator pertumbuhan ekonomi. Maka, jika indeks ini naik, berarti perekonomian sedang tumbuh. Angka indeks produksi industri menggambarkan perkembangan produksi sector industri pengolahan secara lebih dini karena dirancang secara periodik bulanan dan perkembangannya menggunakan periode dasar (tahun dasar=100). Dengan begitu jika nilai indeks produksi industri periode berjalan lebih dari 100, maka 
Purnamasari, et al/Jurnal Ekonomi Syariah Teori dan Terapan Vol. 4 No. 7 Juli 2017: 515-530; PENGARUH HARGA EMAS DUNIA, HARGA MINYAK MENTAH DUNIA DAN INDEKS PRODUKSI INDUSTRI TERHADAP INDEKS SAHAM DI JAKARTA ISLAMIC INDEX (JII) DALAM JANGKA PANJANG DAN JANGKA PENDEK (PERIODE JANUARI 2005-DESEMBER 2015)

industri pengolahan pada periode tersebut mengalami peningkatan jika dibandingkan dengan periode dasar, dan begitu pula sebaliknya.

\section{METODE PENELITIAN}

\section{Pendekatan Penelitian}

Pendekatan yang digunakan dalam penelitian ini adalah pendekatan kuantitatif. Menurut Subana dan Sudrajat (2005:25) penelitian kuantitatif dilihat dari segi tujuan, penelitian ini dipakai untuk menguji suatu teori, menyajikan suatu fakta atau mendeskripsikan statistik, dan untuk menunjukkan hubungan antar variabel serta adapula yang sifatnya mengembangkan konsep, mengembangkan pemahaman atau mendiskripsikan banyak hal.

Metode ekonometrika dalam penelitian ini menggunakan Error Correction Mechanism (ECM) yaitu suatu model yang digunakan untuk mengoreksi persamaan regresi antara variablevariabel yang secara individual tidak stasioner agar kembali ke nilai ekuilibriumnnya di jangka panjang, dengan syarat utama berupa keberadaan hubungan kointegrasi diantara variabel-variabel penyusunnya. Penelitian ini menggunakan perangkat lunak Eviews 8.0 untuk menganalisis data yang dihimpun.

\section{Identifikasi Variabel}

Berdasarkan model analisis dan hipotesis, maka dapat diidentifikasi bahwa harga emas dunia (GOLD), harga minyak mentah dunia (OIL) dan indeks produksi industri (IPI) adalah sebagai variabel independen / bebas sedangkan indeks saham di Jakarta Islamic Index (JII) merupakan variabel dependen/ terikat.

\section{Jenis dan Sumber Data}

Penelitian ini menggunakan data sekunder yang berupa data laporan kevangan pada empat bank syariah yang diambil dari hasil publikasi laoran keuangan dari bank syariah dan juga Bank Indonesia. Data sekunder yang digunakan dalam penelitian ini termasuk data time series yang diterbitkan pada Januari tahun 2005 hingga Desember tahun 2015.

\section{Populasi}

Populasi yang digunakan dalam penelitian ini adalah seluruh data indeks saham Jakarta Islamic Index tahun 2005 hingga tahun 2015.

\section{Sampel}

Sampel yang digunakan dalam penelitian ini adalah sampel jenuh. Hal ini dikarenakan seluruh data dalam populasi digunakan sebagai sampel. Jumlah sampel data penelitian yang digunakan berjumlah 132 data.

\section{Prosedur Pengumpulan Data}

Prosedur pengumpulan data dalam penelitian ini dilakukan dengan cara mengumpulkan data dari jurnal ekonomi, buku-buku pustaka dan bahanbahan yang berhubungan dengan permasalahan yang berfungsi sebagai bahan referensi. Kemudian, data sekunder, yaitu data-data yang diperoleh dari instansi terkait, seperti Bank Indonesia (BI), Badan Pusat Statistik (BPS), Bursa Efek 
Purnamasari, et al/Jurnal Ekonomi Syariah Teori dan Terapan Vol. 4 No. 7 Juli 2017: 515-530; PENGARUH HARGA EMAS DUNIA, HARGA MINYAK MENTAH DUNIA DAN INDEKS PRODUKSI INDUSTRI TERHADAP INDEKS SAHAM DI JAKARTA ISLAMIC INDEX (JII) DALAM JANGKA PANJANG DAN JANGKA PENDEK (PERIODE JANUARI 2005-DESEMBER 2015)

Indonesia (BEI), World Gold Council, dan U.S Energy Information Administration.

\section{Tekhnik Analisis}

Tekhnik analisis yang digunakan adalah Error Correction Mechanism (ECM) merupakan salah satu model dinamik memiliki kemampuan dalam meliput lebih banyak variabel dalam menganalisis fenomena ekonomi jangka pendek dan jangka panjang serta mengkaji konsisten tidaknya model empiris dengan teori ekonometrika. Selain itu, ECM juga dapat mencari pemecahan terhadap variabel time series yang tidak stasioner dan spurious regression dalam analisis ekonometrika.

Dengan menggunakan teknik ini dapat dianalisis hubungan jangka panjang dan jangka pendek antara variabel dependent dan variabel independent-nya disertai teknik analisis untuk mengoreksi ketidakseimbangan jangka pendek menuju pada keseimbangan jangka panjangnya.

\section{HASIL DAN PEMBAHASAN}

Langkah awal dalam mengestimasi model time series adalah dengan menguji stasioneritas data dengan menggunakan uji Augmented Dickey-fuller (ADF). Uji ini diperlukan karena jika data yang digunakan tidak stasioner akan menghasilkan regresi yang lancing (spurious).

Tabel 1.

Hasil Uji Stasioneritas Pada Tingkat Level

\begin{tabular}{|l|l|l|l|}
\hline $\begin{array}{l}\text { Variabe } \\
\text { I }\end{array}$ & $\begin{array}{l}\text { Statisti } \\
\text { k ADF }\end{array}$ & $\begin{array}{l}\text { Probabilita } \\
\text { s }\end{array}$ & Hasil \\
\hline LJII & 0,823 & 0,888 & $\begin{array}{l}\text { Tidak } \\
\text { Stasione }\end{array}$ \\
\hline
\end{tabular}

\begin{tabular}{|l|l|l|l|}
\hline LGOLD & 0,214 & 0,747 & $\begin{array}{l}\text { Tidak } \\
\text { Stasione } \\
r\end{array}$ \\
\hline LOIL & $-0,743$ & 0,392 & $\begin{array}{l}\text { Tidak } \\
\text { Stasione } \\
r\end{array}$ \\
\hline LIPI & $-0,099$ & 0,647 & $\begin{array}{l}\text { Tidak } \\
\text { Stasione } \\
r\end{array}$ \\
\hline
\end{tabular}

Sumber: Hasil estimasi Eviews 8 dan disusun.

Pada Tabel 1 menunjukkan bahwa hasil dari uji stasioneritas keempat variabel ternyata tidak stasioner pada tingkat level. Sehingga dilakukan tahap berikutnya yakni proses differensiasi variabel dan melakukan uji stasioneritas lagi pada variabel di tingkat first difference. Pada Tabel 2 menunjukkan bahwa p-value dari masing-masing variabel menunjukkan lebih rendah dari taraf nyata $5 \%$. Dengan demikian, dapat disimpulkan bahwa semua variabel pada tingkat first difference telah berada pada kondisi stasioner atau tidak mengandung akar unit.

Tabel 2.

Hasil Uji Stasioneritas Pada Tingkat First Difference

\begin{tabular}{|l|l|l|l|}
\hline $\begin{array}{l}\text { Variabe } \\
\text { I }\end{array}$ & $\begin{array}{l}\text { Statisti } \\
\text { k ADF }\end{array}$ & $\begin{array}{l}\text { Probabilita } \\
\text { s }\end{array}$ & Hasil \\
\hline LJII & $-10,042$ & 0,000 & $\begin{array}{l}\text { Stasione } \\
\text { r }\end{array}$ \\
\hline LGOLD & $-13,605$ & 0,000 & $\begin{array}{l}\text { Stasione } \\
r\end{array}$ \\
\hline LOIL & $-7,203$ & 0,000 & $\begin{array}{l}\text { Stasione } \\
r\end{array}$ \\
\hline LIPI & $-13,978$ & 0,000 & $\begin{array}{l}\text { Stasione } \\
r\end{array}$ \\
\hline
\end{tabular}


Purnamasari, et al/Jurnal Ekonomi Syariah Teori dan Terapan Vol. 4 No. 7 Juli 2017: 515-530; PENGARUH HARGA EMAS DUNIA, HARGA MINYAK MENTAH DUNIA DAN INDEKS PRODUKSI INDUSTRI TERHADAP INDEKS SAHAM DI JAKARTA ISLAMIC INDEX (JII) DALAM JANGKA PANJANG DAN JANGKA PENDEK (PERIODE JANUARI 2005-DESEMBER 2015)

Sumber: Hasil estimasi Eviews 8 dan disusun.

\section{Uji Kointegrasi}

Setelah melakukan uji stasioner setiap variabel, langkah selanjutnya adalah melakukan uji kointegrasi. Dapat dikatakan terkointegrasi jika variabel dependen dan independen terdapat hubungan dalam jangka panjang yang akan mendekati atau mencapai kondisi equilibriumnya. Pengujian kointegrasi dilakukan dengan uji Johansen's Cointegration Test. Uji ini menggunakan dua pengujian statistik yang berbeda yaitu trace test dan maximum eigenvalue test. Berikut merupakan hasil uji kointegrasi dengan menggunakan metode Johansen's Cointegration Test.

Tabel 3.

Hasil Uji Kointegrasi dengan Metode Johansen's Cointegration Test (Trace Statistic)

\begin{tabular}{|l|l|l|l|l|}
\hline $\begin{array}{l}\text { Hypothesi } \\
\text { zed No. } \\
\text { of CE(s) }\end{array}$ & $\begin{array}{l}\text { Eigenva } \\
\text { lue }\end{array}$ & $\begin{array}{l}\text { Trac } \\
\mathbf{e} \\
\text { Statis } \\
\text { tic }\end{array}$ & $\begin{array}{l}\mathbf{0 . 0 5} \\
\text { Critic } \\
\text { al } \\
\text { Valu } \\
\mathbf{e}\end{array}$ & $\begin{array}{l}\text { Prob } \\
.^{* *}\end{array}$ \\
\hline None * & 0.2532 & $\begin{array}{l}59.69 \\
78\end{array}$ & $\begin{array}{l}47.85 \\
61\end{array}$ & $\begin{array}{l}0.00 \\
26\end{array}$ \\
\hline At most 1 & 0.1506 & $\begin{array}{l}24.93 \\
96\end{array}$ & $\begin{array}{l}29.79 \\
70\end{array}$ & $\begin{array}{l}0.16 \\
36\end{array}$ \\
\hline At most 2 & 0.0429 & $\begin{array}{l}5.513 \\
9\end{array}$ & $\begin{array}{l}15.49 \\
47\end{array}$ & $\begin{array}{l}0.75 \\
21\end{array}$ \\
\hline At most 3 & 0.0023 & 0.285 & 3.841 & 0.59 \\
& & 5 & 4 & 31 \\
\hline
\end{tabular}

Tabel 4.

Hasil Uji Kointegrasi dengan Metode Johansen's Cointegration Test (Max-

Eigenvalue Test)

\begin{tabular}{|l|l|l|l|l|}
\hline $\begin{array}{l}\text { Hypothesi } \\
\text { zed No. } \\
\text { of CE(s) }\end{array}$ & $\begin{array}{l}\text { Eigenva } \\
\text { lue }\end{array}$ & $\begin{array}{l}\text { Max- } \\
\text { Eigen } \\
\text { Statis } \\
\text { tic }\end{array}$ & $\begin{array}{l}\mathbf{0 . 0 5} \\
\text { Critic } \\
\text { al } \\
\text { Valu } \\
\mathbf{e}\end{array}$ & $\begin{array}{l}\text { Prob } \\
*^{* *}\end{array}$ \\
\hline None * & 0.2532 & $\begin{array}{l}34.75 \\
82\end{array}$ & $\begin{array}{l}27.58 \\
43\end{array}$ & $\begin{array}{l}0.00 \\
51\end{array}$ \\
\hline At most 1 & 0.1506 & $\begin{array}{l}19.42 \\
57\end{array}$ & 21.13 & 0.08 \\
16 & 52 \\
\hline At most 2 & 0.0429 & 5.228 & 14.26 & 0.71 \\
& & 3 & 46 & 28 \\
\hline At most 3 & 0.0023 & 0.285 & 3.841 & 0.59 \\
& & 5 & 4 & 31 \\
\hline
\end{tabular}

Berdasarkan Tabel 3 dan Tabel 4 menunjukkan hasil tes kointegrasi dengan pendekatan Johansen. Hasil menunjukkan bahwa nilai trace statistic lebih besar daripada critical value (Tabel 3) dan nilai max-eigen statistic lebih besar daripada critical value (Tabel 4).

Kemudian, dilakukan estimasi persamaan regresi jangka panjang melalui metode OLS. Hasil estimasi OLS dapat dilihat pada Tabel 4.5.

Tabel 5.

Hasil Estimasi OLS

\begin{tabular}{|l|l|l|}
\hline Variabel & Koefisien & Probabilitas \\
\hline C & $-365,8851$ & 0,0000 \\
\hline GOLD & 0,3872 & 0,0000 \\
\hline OIL & $-0,0808$ & 0,0000 \\
\hline IPI & 3,5004 & 0,0000 \\
\hline Res_2(-1) & 0,9259 & 0,0000 \\
\hline $\mathbf{R}^{\mathbf{2}}$ & 0,9485 & \\
\hline
\end{tabular}


Purnamasari, et al/Jurnal Ekonomi Syariah Teori dan Terapan Vol. 4 No. 7 Juli 2017: 515-530; PENGARUH HARGA EMAS DUNIA, HARGA MINYAK MENTAH DUNIA DAN INDEKS PRODUKSI INDUSTRI TERHADAP INDEKS SAHAM DI JAKARTA ISLAMIC INDEX (JII) DALAM JANGKA PANJANG DAN JANGKA PENDEK (PERIODE JANUARI 2005-DESEMBER 2015)

\begin{tabular}{|l|l|}
\hline $\begin{array}{l}\text { F-Statistik } \\
\text { (Probabilitas) }\end{array}$ & 0,0000 \\
\hline
\end{tabular}

Sumber: Hasil estimasi Eviews 8 dan disusun.

Berdasarkan hasil dari Tabel 5 menunjukkan bahwa variabel GOLD dan IPI berpengaruh signifikan positif terhadap JII. Sedangkan variabel OIL berpengaruh signfikan negatif terhadap JII.

Di tabel ini juga dapat dilihat bahwa variabel Res_2(-1) atau variabel Error Correction Term (ECT) berpengaruh signifikan. Hasil tersebut terlihat dari probabilitas variabel yang berada di bawah taraf nyata 1\%, 5\% dan $10 \%$. Koefisien variabel Res_2(-1) atau koefisien ECT bertanda poistif dan berada pada rentang 0 dan 1 , yaitu $(0,9259)$ yang membuktikan bahwa terjadi keseimbangan dalam jangka panjang.

\section{Uji Error Correction Model (ECM)}

Model ECM digunakan untuk melihat hubungan dinamis jangka pendek dari variabel-variabel yang terkointegrasi. Oleh karena itu untuk melihat hubungan jangka pendek antara variabel independen dengan dependen serta mengoreksi ketidakseimbangan jangka pendek, ialah menggunakan model ECM. Hasil estimasi ECM dapat dilihat pada Tabel 6.

Tabel 6.

Hasil Estimasi ECM

\begin{tabular}{|l|l|l|}
\hline Variabel & Koefisien & Probabilitas \\
\hline C & 2,9073 & 0,1853 \\
\hline DLGOLD & 0,0779 & 0,0214 \\
\hline DLOIL & 0,9794 & 0,0031 \\
\hline DLIPI & 0,0016 & 0,9970 \\
\hline
\end{tabular}

\begin{tabular}{|l|l|l|}
\hline Res_2(-1) & $-0,0412$ & 0,0837 \\
\hline $\mathbf{R}^{2}$ & 0,1076 \\
\hline $\begin{array}{l}\text { F-Statistik } \\
\text { (Probabilitas) }\end{array}$ & 0,0010 \\
\hline
\end{tabular}

Sumber: Hasil estimasi Eviews 8 dan disusun.

Pada Tabel 6 dapat dilihat hasil estimasi model ECM menunjukkan bahwa variabel independen IPI tidak berpengaruh signifikan terhadap variabel dependen. Sedangkan variabel GOLD dan OIL berpengaruh signifikan positif terhadap variabel dependen. Di tabel ini juga dapat dilihat bahwa variabel Res_2(1) atau variabel Error Correction Term (ECT) berpengaruh signifikan. Hasil tersebut terlihat dari probabilitas variabel yang berada di bawah taraf nyata 1\%, $5 \%$ dan $10 \%$.

Koefisien variabel Res_2(-1) atau koefisien ECT bertanda negatif dan berada pada rentang 0 dan 1 , yaitu (0,0412 ) yang membuktikan bahwa terjadi ketidakseimbangan dalam jangka pendek, tetapi koefisien ECT yang jauh dari angka 1 menunjukkan bahwa lambatnya model dalam menyesuaikan ke jangka panjang.

Uji $\boldsymbol{t}$

Pada jangka panjang, berdasarkan hasil estimasi regresi OLS pada Tabel 5, diperoleh hasil dari estimasi regresi yang menunjukkan bahwa nilai koefisien masing-masing variabel independen memiliki nilai yang berbeda-beda. Identifikasi masing-masing variabel untuk model dijelaskan sebagai berikut: 
Purnamasari, et al/Jurnal Ekonomi Syariah Teori dan Terapan Vol. 4 No. 7 Juli 2017: 515-530; PENGARUH HARGA EMAS DUNIA, HARGA MINYAK MENTAH DUNIA DAN INDEKS PRODUKSI INDUSTRI TERHADAP INDEKS SAHAM DI JAKARTA ISLAMIC INDEX (JII) DALAM JANGKA PANJANG DAN JANGKA PENDEK (PERIODE JANUARI 2005-DESEMBER 2015)

1. Koefisien regresi variabel GOLD terhadap indeks saham di Jll adalah sebesar 0,3872 dengan nilai probabilitas 0,000 yang artinya lebih kecil dari taraf nyata $5 \%$. Hasil berada pada daerah $\mathrm{HO}$ ditolak, sehingga parameter ini dalam jangka panjang berpengaruh signifikan positif secara parsial terhadap indeks saham di Jll.

2. Koefisien regresi variabel OIL terhadap indeks saham di JII adalah sebesar -0,0808 dengan nilai probabilitas 0,000 yang artinya lebih kecil dari taraf nyata $5 \%$. Hasil berada pada daerah HO ditolak, sehingga parameter ini berpengaruh signifikan terhadap indeks saham di Jll.

3. Koefisien regresi variabel IPI terhadap indeks saham di JII adalah sebesar 3,5004 dengan nilai probabilitas 0,000 yang artinya lebih kecil dari taraf nyata $5 \%$. Hasil berada pada daerah $\mathrm{HO}$ ditolak, sehingga parameter ini dalam jangka panjang berpengaruh signifikan positif secara parsial terhadap indeks saham di JII.

Sementara pada jangka pendek, dapat dilihat dari hasil estimasi regresi ECM pada Tabel 6. Identifikasi masingmasing variabel untuk model dijelaskan sebagai berikut:

1. Koefisien regresi variabel GOLD terhadap indeks saham di JII adalah sebesar 0,0779 dengan nilai probabilitas 0,0214 yang artinya lebih kecil dari taraf nyata $5 \%$. Hasil berada pada daerah $\mathrm{HO}$ ditolak, sehingga parameter ini dalam jangka pendek berpengaruh signifikan positif secara parsial terhadap indeks saham di JII.

2. Koefisien regresi variabel OIL terhadap indeks saham di JII adalah sebesar 0,9794 dengan nilai probabilitas 0,031 yang artinya lebih kecil dari taraf nyata $5 \%$. Hasil berada pada daerah $\mathrm{HO}$ ditolak, sehingga parameter ini dalam jangka pendek berpengaruh signifikan positif secara parsial terhadap indeks saham di JII.

3. Koefisien regresi variabel IPI terhadap indeks saham di JII adalah sebesar 0,0016 dengan nilai probabilitas 0,9970 yang artinya lebih besar dari taraf nyata $5 \%$. Hasil berada pada daerah $\mathrm{HO}$ diterima, sehingga parameter ini tidak berpengaruh signifikan terhadap indeks saham di JII.

\section{Uji $\boldsymbol{F}$}

Berdasarkan hasil estimasi OLS (jangka panjang) pada Tabel 5, untuk hasil uji $F$ menunjukkan bahwa variabel GOLD, OIL dan IPI dalam jangka panjang berpengaruh signifikan terhadap indeks saham di Jll secara simultan. Dengan nilai probabilitas F-statistik untuk model OLS pada penelitian ini adalah 0,0000.

Sama halnya dengan hasil estimasi ECM pada Tabel 6, variabel GOLD, OIL dan IPI dalam jangka pendek berpengaruh signifikan terhadap indeks saham di JII secara simultan. Dengan nilai probabilitas F-statistik untuk model ECM pada penelitian ini adalah 0,0010.

Uji $\mathbf{R}^{\mathbf{2}}$

Berdasarkan hasil estimasi OLS (jangka panjang) pada Tabel 5 diperoleh 
Purnamasari, et al/Jurnal Ekonomi Syariah Teori dan Terapan Vol. 4 No. 7 Juli 2017: 515-530; PENGARUH HARGA EMAS DUNIA, HARGA MINYAK MENTAH DUNIA DAN INDEKS PRODUKSI INDUSTRI TERHADAP INDEKS SAHAM DI JAKARTA ISLAMIC INDEX (JII) DALAM JANGKA PANJANG DAN JANGKA PENDEK (PERIODE JANUARI 2005-DESEMBER 2015)

nilai koefisien determinasi (R2) sebesar 0,9485 . Hal ini berarti bahwa variasi dari seluruh variabel independen (GOLD, OIL dan IPI) sebesar $94,85 \%$ dapat menjelaskan variabel dependen (JII) sedangkan $5,15 \%$ dijelaskan oleh variabel yang tidak dimasukkan dalam model.

Sementara itu, berdasarkan hasil estimasi ECM (jangka pendek) pada Tabel 6. dapat dilihat bahwa nilai koefisien determinasi (R2) diperoleh sebesar 0,1076. Artinya, hanya $10,76 \%$ indeks saham di JII dapat dijelaskan oleh harga emas dunia (GOLD), harga minyak mentah dunia (OIL) dan indeks produksi industri (IPI) dalam jangka pendek. Sedangkan 89,24\% dijelaskan oleh variabel yang tidak dimasukkan dalam model.

\section{Pembahasan}

\section{Pengaruh Harga Emas Dunia terhadap Jakarta Islamic Index}

Berdasarkan hasil estimasi regresi Tabel 5 dalam jangka panjang dan Tabel 6 dalam jangka pendek, menunjukkan bahwa variabel harga emas dunia (GOLD) dalam jangka panjang maupun pendek berpengaruh signifikan positif terhadap indeks saham di JII. Penelitian ini sejalan dengan penelitian yang dilakukan Witjaksono (2010) tentang Analisis Pengaruh Tingkat Suku Bunga SBI, Harga Minyak Dunia, Harga Emas Dunia, Kurs Rupiah, Indeks Nikkei 225, dan Indeks Dow Jones terhadap IHSG (studi kasus pada IHSG di BEl selama periode 2000-2009) dimana hasil menunjukkan bahwa harga emas dunia berpengaruh signifikan positif terhadap IHSG.
Hal ini disebabkan karena pada periode penelitian, perekonomian dunia mengalami pertumbuhan tiap tahunnya. Peningkatan pertumbuhan ekonomi ini tentunya akan meningkatkan pendapatan rata-rata masyarakat. Di Indonesia sendiri selama tahun 2005-2009, pendapatan per kapita masyarakat Indonesia mengalami rata-rata kenaikan $5,62 \%$ dan 5,8\% di tahun 2010-2014 (www.indonesia-investments.com).

Apabila pendapatan per kapita mengalami kenaikan maka tingkat kesejahteraan masyarakat akan meningkat juga, kesejahteraan masyarakat ini dapat mengakibatkan masyarakat tetap melakukan investasi di pasar modal dan juga berinvestasi pada emas yang dapat dengan mudah dijual kapan saja. Sehingga, kenaikan harga emas dari tahun ke tahun, juga diiringi harga indeks saham JII yang meningkat seiring berkembangnya perekonomian. Hasil ini dapat dijelaskan bahwa sebenarnya investasi pada emas dan saham syariah bersifat substitusi. Ketika harga emas mengalami penurunan yang disebabkan oleh menurunnya perekonomian, sehingga pada saat itu juga, Jll mengalami tren yang menurun. Maka saat itu investor yang berinvestasi pada perusaahaan yang terdaftar di JII merasakan pesimisme kemudian mengalihkan dananya ke instrumen emas. Namun, investor ternyata memilih ke instrumen lain diluar emas karena harga emas pada saat itu juga mengalami penurunan. Sehingga akhirnya harga 
Purnamasari, et al/Jurnal Ekonomi Syariah Teori dan Terapan Vol. 4 No. 7 Juli 2017: 515-530; PENGARUH HARGA EMAS DUNIA, HARGA MINYAK MENTAH DUNIA DAN INDEKS PRODUKSI INDUSTRI TERHADAP INDEKS SAHAM DI JAKARTA ISLAMIC INDEX (JII) DALAM JANGKA PANJANG DAN JANGKA PENDEK (PERIODE JANUARI 2005-DESEMBER 2015)

emas dunia dan indeks saham di Jll memiliki hubungan yang positif.

\section{Pengaruh Harga Minyak Mentah Dunia terhadap Jakarta Islamic Index}

Variabel harga minyak mentah dunia memiliki respon yang berbeda terhadap indeks saham di JII dalam jangka panjang dan jangka pendek. Pada jangka panjang, harga minyak mentah dunia berpengaruh signifikan negatif terhadap indeks saham di Jll. Sedangkan untuk jangka pendek, harga minyak mentah dunia memiliki pengaruh signifikan positif terhadap indeks saham di JII.

Indonesia adalah negara importer minyak dunia. Harga minyak mentah dunia yang fluktuatif dan cenderung rentan terhadap perekonomian membuat investor berpikir ulang kembali dalam menginvestasikan uangnya di komoditas minyak. Kenaikan harga minyak akan menekan prospek saham dengan karakteristik tertentu yakni saham yang bahan bakunya mayoritas berbasis impor dan saham bank serta properti. Perusahaan yang terdaftar dalam JII tidak didominasi oleh perusahaan produsen minyak. Maka dari itu, dalam jangka panjang harga minyak mentah dunia berpengaruh signifikan negatif terhadap JIl. Samsul (2006) menambahkan bahwa kenaikan harga minyak merupakan suatu berita buruk yang secara umum dapat berpengaruh negatif terhadap harga saham.

Berbeda dalam jangka pendeknya, harga minyak mentah dunia memiliki pengaruh signifikan positif terhadap Jll. Kondisi ini terjadi karena dalam jangka pendek, kenaikan harga minyak dunia dipicu sentimen positif dari saham pertambangan investor yang secara signifikan mempengaruhi pergerakan JIl.

\section{Pengaruh Indeks Produksi Industri terhadap Jakarta Islamic Index}

Variabel indeks produksi industri berpengaruh signifikan positif dalam jangka panjang. Hal ini terlihat dari hasil estimasi OLS pada Tabel 5. Kemudian, hasil berbeda ditunjukkan variabel indeks produksi industri dalam jangka pendek. Pada estimasi ECM di Tabel 6, indeks produksi industri tidak berpengaruh signifikan terhadap indeks saham di Jll.

Sejalan dengan penelitian yang dilakukan Fathkhurrozaq (2012) bahwa indeks produksi industri memiliki pengaruh positif pada harga saham di IHSG. Indeks produksi industri yang memiliki pengaruh positif mengindikasikan bahwa ketika indeks produksi industri mengalami kenaikan maka indeks saham di Jll juga mengalami kenaikan. Hal ini disebabkan karena pertumbuhan produksi dalam industri memiliki efek positif pada pasar keuangan, menyebabkan harga saham yang lebih tinggi dan optimisme investor.

Hasil penelitian ini menjelaskan bahwa dalam jangka pendek, indeks produksi industri tidak berpengaruh signifikan terhadap indeks saham di Jakarta Islamic Index (JII). Hal ini disebabkan karena indeks produksi industri adalah indikator pertumbuhan ekonomi, dimana pertumbuhan ekonomi 
Purnamasari, et al/Jurnal Ekonomi Syariah Teori dan Terapan Vol. 4 No. 7 Juli 2017: 515-530; PENGARUH HARGA EMAS DUNIA, HARGA MINYAK MENTAH DUNIA DAN INDEKS PRODUKSI INDUSTRI TERHADAP INDEKS SAHAM DI JAKARTA ISLAMIC INDEX (JII) DALAM JANGKA PANJANG DAN JANGKA PENDEK (PERIODE JANUARI 2005-DESEMBER 2015)

didefiniskan sebagai penjelasan mengenai faktor-faktor yang menentukan kenaikan output per kapita dalam jangka panjang, dan penjelasan mengenai bagaimana faktor-faktor tersebut berinteraksi satu sama lain, sehingga terjadi proses pertumbuhan.

\section{SIMPULAN}

Berdasarkan pembahasan hasil penelitian tentang pengaruh jangka panjang dan jangka pendek harga emas dunia, harga minyak mentah dunia dan indeks produksi terhadap indeks saham di Jakarta Islamic Index periode Januari 2005 hingga Desember 2015, terdapat beberapa simpulan yang dapat diambil yaitu sebagai berikut:

1. Terdapat pengaruh signifikan jangka panjang antara harga emas dunia, harga minyak mentah dunia dan indeks produksi industri terhadap indeks saham di Jakarta Islamic Index pada Januari 2005 hingga Desember 2015 secara simultan.

2. Terdapat pengaruh signifikan jangka pendek antara harga emas dunia, harga minyak mentah dunia dan indeks produksi industri terhadap indeks saham di Jakarta Islamic Index pada Januari 2005 hingga Desember 2015 secara simultan.

3. Harga emas dunia dan harga minyak mentah dunia berpengaruh signifikan terhadap indeks saham di Jakarta Islamic Index dalam jangka panjang dan jangka pendek secara parsial. Namun, indeks produksi industri berpengaruh signifikan terhadap indeks saham di Jakarta Islamic Index dalam jangka panjang, akan tetapi tidak berpengaruh dalam jangka pendek.

4. Terdapat pengaruh antara harga emas dunia, harga minyak mentah dunia dan indeks produksi industri terhadap indek saham di Jakarta Islamic Index secara simultan.

\section{DAFTAR PUSTAKA}

Alma, Buchari dan Donni Juni Priansa. 2009. Manajemen Bisnis Syariah. Bandung: CV Alvabeta.

Alwi, Iskandar Z. 2003. Pasar Modal, Teori dan Aplikasi. Jakarta: Nasindo Internusa.

Antonio, Muhammad Syafii dkk. 2013. The Islamic Capital Market Volatility: A Comparative Study Between in Indonesia and Malaysia. Bulletin of Monetary, Economics and Banking. 378 - 399

Fatkhurrozaq, Ancas Andhika. 2012. Dampak Indikator Makroekonomi terhadap IHSG. Skripsi tidak diterbitkan. Surabaya: Universitas Airlangga.

Gokmenoglu, Korhan K. dan Negar Fazlollahi. 2015. The Interactions among Gold, Oil, and Stock Market: Evidence from S\&P500. Procedia Economics and Finance 25 ( 2015 ) $478-488$.

Gujarati, D. N., \& Porter, D. C. 2003. Basic Econometrics, 6th edition. Jakarta: Erlangga.

Hartono, Jogiyanto. 2012. Teori Portofolio dan Analisis Investasi. BPFE-Yogyakarta.

Hartono, Halim Prayoga. 2013. Analisis Kausalitas Timbal Balik antara Harga Emas, Harga Minyak Mentah, IHSG, Suku Bunga, Nilai Tukar dan Inflasi di Indonesia Periode 2005-2012. Skripsi tidak diterbitkan. Surabaya: Universitas Airlangga. 
Purnamasari, et al/Jurnal Ekonomi Syariah Teori dan Terapan Vol. 4 No. 7 Juli 2017: 515-530; PENGARUH HARGA EMAS DUNIA, HARGA MINYAK MENTAH DUNIA DAN INDEKS PRODUKSI INDUSTRI TERHADAP INDEKS SAHAM DI JAKARTA ISLAMIC INDEX (JII) DALAM JANGKA PANJANG DAN JANGKA PENDEK (PERIODE JANUARI 2005-DESEMBER 2015)

Hidayat, Taufik. 2011. Buku Pintar Investasi Syariah. Jakarta: Mediakita.

Huda, Nurul dan Mustafa Edwin Nasution. 2008. Investasi pada Pasar Modal Syariah. Jakarta: Kencana.

Jaka, Isgiyarta. 2009. Teori Akuntansi dan Laporan Kevangan Islami. Semarang: Badan Penerbit Universitas Diponegoro Semarang.

Karim, Adiwarman Aswar. 2005. Ekonomi Islam Suatu Kajian Kontemporer. Jakarta: Rineka Cipta.

Lestari, Elly. 2011. Pengujian Reaksi Pasar Terhadap Perusahaan yang Melakukan Stock Split Berdasarkan Rasio Split di Bursa Efek Indonesia. Tesis. Universitas Airlangga.

Mustafa, Qutb Sano. 2000. Al-Istitsmar ahkamuhu wa Dawabituhu fi al-Figh alIslami. Jordan: Dar al-Nafais.

Rivai, H. Veithzal dkk. 2010. Islamic Finance Management. Bogor: Ghalia Indonesia.

Riyandono, Muhamad Nafik H. 2009. Bursa Efek dan Investasi Syariah. Jakarta: Serambi.

Subana, M. dan Sudrajat. 2005. DasarDasar Penelitian Ilmiah. Bandung: Pustaka Setia.

Samsul, Mohamad. 2006. Pasar Modal dan Manajemen Portofolio. Jakarta: Erlangga.

Suryomurti, Wiku. 2011. Super Cerdas Investasi Syariah. Jakarta: Qultum Media

Sutedi, Adrian. 2011. Pasar Modal Syariah: Sarana Investasi Kevangan Berdasarkan Prinsip Syariah. Jakarta Timur: Sinar Grafika.

Utomo, Venny Julia. 2014. Efek Hari Raya Idul Fitri Terhadap Abnormal Return dan Trading Volume Activity pada Emiten yang Masuk dalam Daftar ISSI Periode 2011-2013. Skripsi tidak diterbitkan. Surabaya: Universitas Airlangga.

Wahid, Nazarudin Abdul. 2010. Memahami dan Membedah Obligasi pada Perbankan Syariah. Yogyakarta: Ar-Ruzz Media.

Wicaksono, Yohanes Visantus. 2014. Pengaruh Fenomena The Monday Effect terhadap Return Saham di Bursa Efek Indonesia. Skripsi tidak diterbitkan. Surabaya: STIE Perbanas Surabaya.

Witjaksono, Ardian Agung. 2010. Analisis Pengaruh Tingkat Suku Bunga SBI, Harga Minyak Dunia, Harga Emas
Dunia, Kurs Rupiah, Indeks Nikkei 225 dan Indeks Dow Jones terhadap IHSG. Tesis tidak diterbitkan. Semarang: Universitas Diponegoro www.bi.go.id www.gold.com www.ojk.go.id 